\title{
Indirect regulation of 3-hydroxy-3-methylglutaryl coenzyme $A$ reductase by oestradiol in the rabbit corpus luteum*
}

\author{
M. P. McLean and J. B. Miller ${ }^{\dagger}$ \\ Department of Physiology and Biophysics and $\dagger$ Department of Obstetrics and Gynecology, \\ University of Illinois College of Medicine at Chicago, Chicago, Illinois 60612, U.S.A.
}

\begin{abstract}
Summary. Rabbits were given 50 i.u. hCG, i.v., to initiate ovulation and pseudopregnancy (Day 0) and were treated, s.c., with or without a 1-cm Silastic oestradiol implant. Serum progesterone concentrations were measured at 4-day intervals and 3-hydroxy-3methylglutaryl-coenzyme A (HMG-CoA) reductase activity was estimated by the conversion of $\mathrm{HMG}$ to mevalonate in microsomes from corpora lutea removed on Days $4,8,12,16$ and 20 of pseudopregnancy (4 rabbits/day). Total HMG-CoA reductase activity was significantly $(P<0.05)$ higher in control rabbits on Days 8 and 12 $(5.29 \pm 0.63$ and $5.5 \pm 0.28 \mathrm{nmol} / \mathrm{min} / \mathrm{mg}$ protein, respectively) compared to oestradioltreated rabbits $(2.57 \pm 0.25$ and $4.03 \pm 0.23 \mathrm{nmol} / \mathrm{min} / \mathrm{mg}$ protein, respectively). On Days 16 and 20, total HMG-CoA reductase activity was not different in control and oestradiol-treated animals. There was no difference in the levels of the active fraction of HMG-CoA reductase, which represented $<20 \%$ of the total enzyme activity, in control and oestradiol-treated rabbits ( $<780 \mathrm{pmol} / \mathrm{min} / \mathrm{mg}$ protein, Day 12$)$. These results indicate that oestradiol does not alter the active form, but can reduce the total activity of $\mathrm{HMG}-\mathrm{CoA}$ reductase in the rabbit corpus luteum without a decline in serum progesterone. Therefore, neither total nor active forms of $\mathrm{HMG}-\mathrm{CoA}$ reductase are directly related to progesterone secretion. This suggests that other sources of cholesterol may contribute to progesterone production in the rabbit.
\end{abstract}

Keywords: HMG CoA reductase; corpus luteum; progesterone synthesis; oestradiol action; lipoproteins

\section{Introduction}

As early as 1933, Schoenheimer \& Breusch (1933) had deduced that cholesterol regulated its own synthesis. The enzyme responsible for this process was found to be 3-hydroxy-3-methylglutarylcoenzyme A (HMG-CoA) reductase (EC 1.1.1.34), the rate-limiting enzyme for de-novo cholesterol biosynthesis (Shapiro \& Rodwell, 1972). This enzyme occurs exclusively in the microsomal membrane fraction of cell homogenates, with over $80 \%$ of the enzyme being associated with the smooth endoplasmic reticulum, Golgi and plasma membrane (Goldfarb, 1972). HMG-CoA reductase exists in an active (dephosphorylated) and an inactive (phosphorylated) form (Beg \& Brewer, 1978).

Several hormones have been implicated in the regulation of $\mathrm{HMG}-\mathrm{Co} A$ reductase. Those that increase $\mathrm{HMG}-\mathrm{CoA}$ reductase activity include insulin (White, 1972), thyroid hormone (Guder et al., 1968), adrenaline and noradrenaline (Edwards, 1973). Hormones which have been shown to decrease HMG-CoA reductase include glucagon (Huber et al., 1973) and the glucocorticoids (Dugan et al., 1974). The sex steroids, oestrogens, progestagens and androgens, can also suppress

\footnotetext{
${ }^{*}$ Reprint requests to Dr J. B. Miller.
} 
reductase activity of human fibroblasts when added to culture medium (Brown \& Goldstein, 1974) or hepatic reductase activity when fed or injected into rats or mice (Mukherjee \& Bhose, 1968; Kandutsch \& Packie, 1970). In contrast, oestradiol stimulates HMG-CoA reductase activity in uterine epithelial cells (Wilce et al., 1984) and rat corpora lutea (Azhar et al., 1985). This suggests that oestradiol may regulate HMG-CoA reductase activity differently in target tissues that have high oestrogen receptor levels than in non-target tissues.

Oestradiol is the principal luteotrophic hormone in the rabbit, and it can maintain the usual patterns of serum progesterone concentrations during pseudopregnancy in the hypophysectomized animal (Bill \& Keyes, 1983). Although it is presumed that oestradiol acts via an oestrogen receptor to regulate luteal function (Mills \& Osteen, 1977; Miller \& Keyes, 1978; Miller \& Toft, 1983), the cellular mechanisms through which oestradiol regulates steroidogenesis in this tissue are as yet unknown. In the rabbit corpus luteum, the level of HMG-CoA reductase activity peaks on Day 5 of pregnancy or pseudopregnancy, then rapidly declines on Days 5-7 to intermediate values which are maintained throughout the remainder of pregnancy or pseudopregnancy (Kovanen et al., 1978). Coincident with the decrease in HMG-CoA reductase activity is an increase in oestradiol binding in corpora lutea (Mills \& Osteen, 1977; Miller \& Toft, 1983) and a decrease in plasma cholesterol (Zilversmit et al., 1972). These changes occur within a span of 2-3 days during early luteal development. This suggests that oestradiol may regulate de-novo cholesterol synthesis or its utilization by the corpus luteum. The purpose of the present study was therefore to examine the effect of (1) oestradiol on HMG-CoA reductase activity during pseudopregnancy and (2) decreased serum cholesterol concentrations on luteal HMG-CoA reductase activity and progesterone production in the rabbit. Some of the results have been presented in abstract form (McLean \& Miller, 1986b).

\section{Materials and Methods}

Chemicals and materials. Mevalonic acid, HMG-CoA, NADPH, glucose 6-phosphate, glucose 6-phosphate dehydrogenase, hCG, and a cholesterol kit were obtained from Sigma Chemical Co. (St Louis, MO). 4-Aminopyrazolo(3,4-d)pyrimidine was a product of Aldrich Chemical Co. (Milwaukee, WI). Silica gel G thin-layer chromatography plates were obtained from Analtech (Newark, DE). DL-3-Hydroxy-3-methyl-[3-14 C]glutaryl-CoA, $\left[5-{ }^{3} \mathrm{H}\right] \mathrm{mevalonic}$ acid, $\left[1,2,6,7-{ }^{3}\right]$ progesterone and $\left[2,4,6,7-{ }^{3} \mathrm{H}(\mathrm{N})\right]$ oestradiol were obtained from New England Nuclear Co. (Boston, MA). Xylazine (Rompun, $20 \mathrm{mg} / \mathrm{ml}$ ) was obtained from Baynet (Shawnee, KS), and ketamine (Ketalar; $100 \mathrm{mg} / \mathrm{ml}$ ) was obtained from Parke-Davis (Morris Plains, NJ). The competitive inhibitor of HMG CoA reductase (compactin ML 236B) was a gift from Dr S. Silavin and Dr J. Strauss III (University of Pennsylvania, Philadelphia, PA) who had obtained this drug from Dr A. Endo (San Kyo, Ltd, Tokyo, Japan).

Animals. Mature female New Zealand White rabbits $(3.5 \mathrm{~kg}$ ) were obtained from Langshaw Farms (Augusta, MI) and maintained in individual cages under controlled conditions with free access to lab chow and water. Pseudopregnancy was induced with 50 i.u. hCG; the day of hCG injection was designated Day 0 . To examine the effect of oestradiol during late pseudopregnancy (Day 20), rabbits were hysterectomized on Day 1 to remove any uterine luteolytic factors which would cause luteal regression. Hysterectomies were performed under sterile conditions via a mid-ventral incision, using xylazine ( $40 \mathrm{mg}$, i.m.) and ketamine $(200 \mathrm{mg}$, i.m.) as anaesthetics. An empty Silastic implant or an implant containing $1.0 \mathrm{~cm}$ oestradiol-173 (Holt et al., 1975) was implanted at the base of the neck at the time of hCG injection. Blood samples were taken from the marginal ear vein beginning on Day 0 and every 4 th day thereafter until the animals were killed to obtain corpora lutea for HMG-CoA reductase measurements. On each of Days 4, 8, 12,16 and 20, 4 animals were killed by cervical dislocation.

Treatment of blood samples. Blood samples were taken from the marginal ear vein, allowed to clot for $24 \mathrm{~h}$ at $4^{\circ} \mathrm{C}$ and centrifuged at $800 \mathrm{~g}$ for $20 \mathrm{~min}$ at $4^{\circ} \mathrm{C}$. The serum was removed and stored at $-20^{\circ} \mathrm{C}$ until steroid determinations could be made. All serum samples from an individual rabbit were analysed in the same assay and each assay included samples from control and experimental animals.

Serum cholesterol determination. Cholesterol was assayed by the cholesterol oxidase method (Allain et al., 1974) using a kit sold by Sigma. Serum samples $(10 \mu \mathrm{l})$ were assayed in duplicate and, after cholesterol reagent addition, sample absorbance was determined spectrophotometrically. Serum cholesterol was determined by comparison to known cholesterol standards and expressed in $\mathrm{mg} / \mathrm{dl}$.

Serum oestradiol determination. Oestradiol concentrations were measured in samples, taken on the day of HMGCoA reductase determination, using a specific rabbit antiserum (GDN No. 930) raised against 17ß-oestradiol-11hemisuccinate conjugated to bovine serum albumin. The specificity of the antiserum has been described by England 
et al. (1974). Each sample was extracted with benzene and chromatographed on Sephadex LH-20 columns using a benzene:methanol $(9: 1, \mathrm{v} / \mathrm{v})$ solvent system (Carr et al., 1971). Samples were assayed in duplicate at $4^{\circ} \mathrm{C}$ and incubated with antibody (final dilution of 1:120000) and $\left[{ }^{3} \mathrm{H}\right]$ oestradiol. Bound ligand was separated from free by charcoal absorption $(0.25 \%$ Norit A and $0.025 \%$ dextran T70 in PBS). This assay has a sensitivity of $0.2-0.3 \mathrm{pg}$, and an average $50 \%$ inhibition point of $12-15 \mathrm{pg}$. The mass of oestradiol in each sample was corrected for procedural losses (recoveries averaged $65 \%$ ) and oestradiol was expressed as $\mathrm{pg} / \mathrm{ml}$ serum.

Serum progesterone determination. Progesterone concentrations were measured throughout pseudopregnancy (Days $0,4,8,12,16,20)$ by the radioimmunoassay described by Day \& Birnbaumer (1980). The antiserum used (GDN No. 337) was raised in rabbits against progesterone-11-chloroformate conjugated to bovine serum albumin and has been characterized by Gibori et al. (1977). Each sample was extracted into hexane and assayed in duplicate with $\left[{ }^{3} \mathrm{H}\right]$ progesterone and antibody (final dilution of 1:5000). Bound ligand was separated from free by charcoal $(0.25 \%$ Norit A and $0.25 \%$ dextran T70). Results were calculated using the logit-log weighted-linear regression program of Rodbard et al. (1980). The inter- and intra-assay coefficients of variation were $5 \cdot 9 \%(n=22)$ and $7 \cdot 4,6 \cdot 5$ and $3.6 \%$ at 20,45 and $60 \%$ binding, respectively $(n=10)$. Serum progesterone concentrations from each rabbit have been normalized assuming $10 \mathrm{CL}$ per animal.

Determination of $H M G-C o A$ reductase. Activity was measured by the method of Kovanen et al. (1978) with slight modifications. Rabbit ovaries were removed after cervical dislocation and placed in cold $\mathrm{HBSS}\left(4^{\circ} \mathrm{C}\right)$. Corpora lutea were dissected out on ice and 3-6 corpora lutea were homogenized in $1 \mathrm{ml}$ buffer containing $0 \cdot 3 \mathrm{M}$-sucrose, $25 \mathrm{~mm}-2$ mercaptoethanol, $5 \mathrm{~mm}$-dithiothreitol, $10 \mathrm{~mm}$-EDTA, and either $50 \mathrm{~mm}-\mathrm{NaCl}$ or $50 \mathrm{~mm}-\mathrm{NaF}$ (pH $7 \cdot 0$ ). Sodium fluoride was included in the homogenization buffer to inhibit protein phosphatase activity which activates the $\mathrm{HMG}-$ $\mathrm{CoA}$ reductase (Ingebritsen et al., 1981). Thus, corpora lutea isolated in $50 \mathrm{~mm}-\mathrm{NaCl}$ buffer represents an estimation of the total HMG-CoA reductase activity whereas luteal tissue isolated in $50 \mathrm{~mm}-\mathrm{NaF}$ buffer represents an estimation of the active enzyme level. The homogenization was performed at $4^{\circ} \mathrm{C}$ with a Dounce homogenizer using 20 strokes each with a loose and tight fitting pestle. The resulting homogenate was centrifuged at $20000 \mathrm{~g}$ for $20 \mathrm{~min}$ to remove unbroken cells and nuclei and the supernatant was centrifuged at $100000 \mathrm{~g}$ for $60 \mathrm{~min}$ to isolate luteal microsomes. The microsomes were resuspended in $1.0 \mathrm{ml}$ buffer containing $0.1 \mathrm{M}$-potassium phosphate $(\mathrm{pH} 7.5)$ and $5 \mathrm{~mm}-$ dithiothreitol. A fraction of the resuspended microsomes $(10 \mu \mathrm{l})$ was used to estimate protein content using the technique of Bradford (1976). HMG-CoA reductase activity in luteal microsomes was estimated by assaying 15 and $30 \mu \mathrm{g}$ microsomal protein in $190 \mu \mathrm{l}$ solution containing $0 \cdot 1 \mathrm{M}$-potassium phosphate, $2.5 \mathrm{~mm}-\mathrm{NADPH}, 10 \mathrm{~mm}$-glucose-6phosphate, $10 \mathrm{~mm}$-sodium EDTA, and $5 \mathrm{~mm}$-dithiothreitol ( $\mathrm{pH} \mathrm{7.5).} \mathrm{Microsomes} \mathrm{were} \mathrm{preincubated} \mathrm{in} \mathrm{this} \mathrm{solution}$ for $10 \mathrm{~min}$ at $37^{\circ} \mathrm{C}$, after which $10 \mu \mathrm{l} \mathrm{DL}-3$-hydroxy-3-methyl-[3 $\left.3^{14} \mathrm{C}\right]$ glutaryl CoA $(10000-12000 \mathrm{c} . \mathrm{p} . \mathrm{m}$.) to a final concentration of $87 \mu \mathrm{M}$ was added to start the incubation. Incubation was carried out at $37^{\circ} \mathrm{C}$ for $30 \mathrm{~min}$ and was stopped by the addition of $30 \mu \mathrm{l} 5 \mathrm{~N}-\mathrm{HCl}$. [5- $\left.{ }^{3} \mathrm{H}\right] \mathrm{Mevalonic}$ acid $(2 \mu \mathrm{M} ; 20000-40000 \mathrm{c}$.p.m. $)$ was then added to each incubate and the incubation continued for $30 \mathrm{~min}$. About $500 \mathrm{mg}$ sodium sulphate were added to each incubation tube and the mevalonic acid was extracted twice using ether $\left(8 \mathrm{ml}\right.$ total). The ether was evaporated to dryness under $\mathrm{N}_{2}$ gas, the residue dissolved in $80 \mu \mathrm{l}$ acetone containing $0.2 \mathrm{mg}$ unlabelled mevalonic acid and applied to silica gel $\mathrm{G}-\mathrm{thin}$ layer chromatography plates. Plates were developed in acetone:benzene $(1: 1, \mathrm{v} / \mathrm{v})$ and the mevalonate spots were identified by exposure to iodine vapour. Spots were scraped into scintillation vials and counted in $10 \mathrm{ml} 3 \mathrm{a} 70 \mathrm{~b}$ scintillation fluid. The ${ }^{14} \mathrm{C}$ radioactivity incorporated into mevalonate was calculated using $\left[{ }^{3} \mathrm{H}\right] \mathrm{mevalonate}$ to correct for procedural loss (recovery averaged 45-50\%). Enzyme activity was expressed as nmol mevalonate formed per min per mg protein.

4-Aminopyrazolo (3,4-d) pyrimidine administration. 4-Aminopyrazolo(3,4-d) pyrimidine (APP) was used to determine the effect of reduced serum cholesterol concentrations (Morrin et al., 1979) on progesterone production and HMG-CoA reductase activity in oestrogen-treated rabbits. On Days 9-11, oestrogen-treated rabbits were injected with APP $(25 \mathrm{mg} / \mathrm{ml}$ in saline, $10 \mathrm{mg} / \mathrm{kg}, \mathrm{pH} 2.5)$ or saline administered i.p. Daily blood samples were taken just before each APP injection for the determination of serum cholestrol and progesterone. Rabbits were killed on Day 12 and the corpora lutea removed for $\mathrm{HMG}-\mathrm{CoA}$ reductase determination.

Dissociation of rabbit luteal tissue and incubation with compactin. Corpora lutea were dissected on Day 10 of pseudopregnancy and dissociated as previously described (McLean \& Miller, 1985). The dissociation medium contained $250 \cup$ collagenase $/ \mathrm{ml}, 50 \mu \mathrm{g} \mathrm{DNase} / \mathrm{ml}, 750 \mu \mathrm{g}$ trypsin inhibitor $/ \mathrm{ml}, 20 \mathrm{mg} \mathrm{BSA} / \mathrm{ml}$, and $100 \mu \mathrm{g}$ gentamicin $/ \mathrm{ml}$ in HBSS.

Dissociated luteal cells were incubated ( $100000 \mathrm{cells} / \mathrm{ml}$ ) for $1 \mathrm{~h}$ in $\mathrm{HBSS}(6 \mathrm{ml})$ gassed with $95 \% \mathrm{O}_{2}$ and $5 \% \mathrm{CO}_{2}$ at $37^{\circ} \mathrm{C}$ and then $0-10 \mu \mathrm{g}$ compactin $/ \mathrm{ml}$ was added for 4 additional hours of incubation. Media fractions ( $1 \mathrm{ml}$ ) containing cells and medium were removed each hour, cells were separated by centrifugation ( $500 \mathrm{~g}$ for $5 \mathrm{~min}$ ) and the media stored for progesterone analysis.

Statistical analysis. Results are expressed as the mean \pm s.e.m. Values were compared by analysis of variance and, when significant differences were noted, groups were compared using Student-Newman-Keuls multiple comparison test (Zar, 1974). A $P$ value of $<0.05$ was considered significant. 


\section{Results}

Serum oestradiol, progesterone and cholesterol concentrations

Rabbits treated with a $1 \cdot 0-\mathrm{cm}$ oestradiol implant had significantly elevated oestradiol values when compared to animals receiving an empty implant (Table 1). Even though oestradiol concentrations were different in control and oestradiol-treated animals, serum cholesterol and progesterone did not differ in the non-hysterectomized rabbits (Table 1). Oestradiol treatment maintained elevated serum progesterone concentrations in hysterectomized animals on Days 16 and 20 of pseudopregnancy as seen previously (Miller \& Keyes, 1976), but no differences in serum cholesterol values were observed (Table 1).

Table 1. The effect of oestrogen on serum sterol levels in pseudopregnant rabbits

\begin{tabular}{|c|c|c|c|c|c|c|}
\hline & \multicolumn{4}{|c|}{ Rabbits with intact uterus } & \multicolumn{2}{|c|}{ Hysterectomized rabbits } \\
\hline & Day 4 & Day 8 & Day 12 & Day 16 & Day 16 & Day 20 \\
\hline \multicolumn{7}{|c|}{ Progesterone $(\mathrm{ng} / \mathrm{ml})$} \\
\hline Control & $6 \cdot 6 \pm 1 \cdot 0$ & $14 \cdot 4 \pm 1.8$ & $13.9 \pm 1.8$ & $8.5 \pm 1.7$ & $15 \cdot 7 \pm 2 \cdot 7$ & $7 \cdot 2 \pm 0.4$ \\
\hline Oestradiol & $6.2 \pm 0.9$ & $12 \cdot 7 \pm 1 \cdot 4$ & $11 \cdot 3 \pm 2 \cdot 4$ & $8 \cdot 5 \pm 1 \cdot 2$ & $17 \cdot 2 \pm 3.6$ & $13.6 \pm 1.9$ \\
\hline \multicolumn{7}{|c|}{ Cholesterol $(\mathrm{mg} / \mathrm{dl})$} \\
\hline Control & $68 \cdot 3 \pm 11 \cdot 3$ & $68 \cdot 8 \pm 8 \cdot 5$ & $67.8 \pm 7.0$ & $72 \cdot 1 \pm 9 \cdot 0$ & $63.4 \pm 3.8$ & $62 \cdot 0 \pm 5 \cdot 1$ \\
\hline Oestradiol & $79 \cdot 9 \pm 8 \cdot 4$ & $73 \cdot 9 \pm 5 \cdot 6$ & $75 \cdot 5 \pm 6 \cdot 6$ & $70 \cdot 5 \pm 6 \cdot 4$ & $73 \cdot 1 \pm 6 \cdot 8$ & $71 \cdot 7 \pm 4.9$ \\
\hline \multicolumn{7}{|c|}{ Oestradiol $(\mathrm{pg} / \mathrm{ml})$} \\
\hline Control & $2 \cdot 4 \pm 0.4$ & $3.67 \pm 0.5$ & $2 \cdot 34 \pm 0.2$ & $4 \cdot 3 \pm 1 \cdot 0$ & - & $3 \cdot 9 \pm 2 \cdot 1$ \\
\hline Oestradiol & $15 \cdot 4 \pm 2 \cdot 9$ & $10 \cdot 7 \pm 1 \cdot 5$ & $10 \cdot 1 \pm 2 \cdot 4$ & $9 \cdot 7 \pm 1 \cdot 0$ & - & $14 \cdot 4 \pm 2 \cdot 2$ \\
\hline
\end{tabular}

Values are mean \pm s.e.m. for 4 observations.

\section{$H M G-C o A$ reductase activity in the corpus luteum}

Rabbits treated with and without oestradiol had similar levels of total HMG-CoA reductase activities on Day 4 (Fig. 1), but by Days 8 and 12 of pseudopregnancy HMG-CoA reductase activity was significantly reduced in oestradiol-treated animals. The effect of oestradiol on total HMG-CoA reductase activity was no longer observed by Day 16 of pseudopregnancy in hysterectomized rabbits. The active form of $\mathrm{HMG}-\mathrm{CoA}$ reductase represented less than $20 \%$ of the total reductase enzyme activity present in luteal microsomes.

\section{Effect of lower serum cholesterol on $H M G-C o A$ reductase activity}

Rabbits treated with APP had significantly $(P<0.05)$ lower serum cholesterol concentrations compared to control animals $(23.8 \pm 7 \cdot 2$ vs $60 \cdot 1 \pm 18.9 \mathrm{mg} / \mathrm{dl}$, respectively, Day 12$)$. Since cholesterol measurements were made $24 \mathrm{~h}$ after APP administration, the cholesterol values in APP. treated animals represent the highest levels reached during drug treatment. There was, however, no change in the serum progesterone concentrations $(14.8 \pm 3.6 v s 17.9 \pm 2.4 \mathrm{ng} / \mathrm{ml}$ in APP-treated and control rabbits, Day 12). The total activity of $\mathrm{HMG}-\mathrm{CoA}$ reductase increased slightly with APP treatment, but this change was not significant $(4.28 \pm 0.66$ vs $5.2 \pm 0.5 \mathrm{nmol} / \mathrm{min} /$ protein). In contrast, there was a significant $(P<0.05)$ increase in the active form of HMG-CoA reductase in luteal microsomes on Day 12 of pseudopregnancy from rabbits treated with APP $(0.90 \pm 0.14 v s$ $1 \cdot 82 \pm 0 \cdot 26 \mathrm{nmol} / \mathrm{min} / \mathrm{mg} /$ protein).

\section{Inhibition of $H M G-C o A$ reductase in vitro}

The addition of compactin $(0.001-10 \mu \mathrm{g} / \mathrm{ml})$, a competitive inhibitor of HMG-CoA reductase (Kaneko et al., 1978; Silavin \& Strauss, 1983), had no effect on progesterone secretion by dissociated 


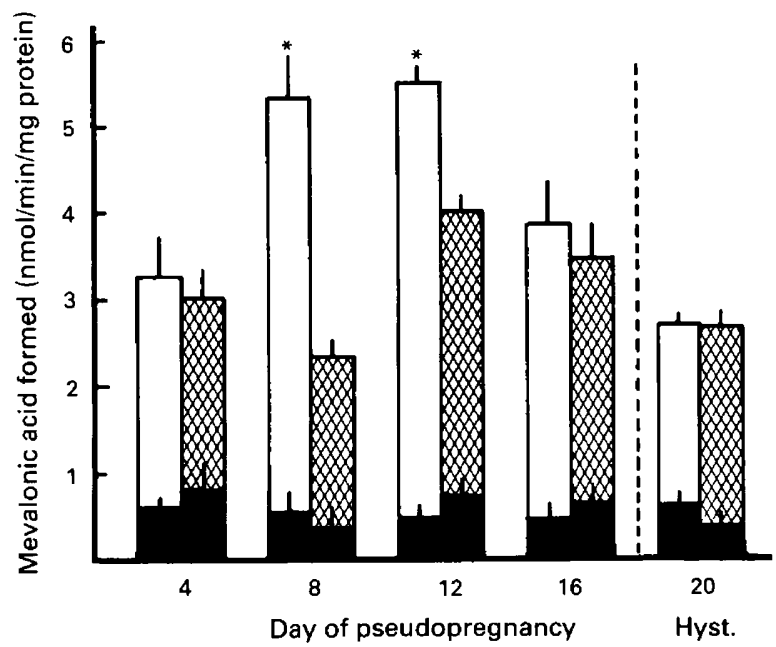

Fig. 1. Luteal cell HMG-CoA reductase activity in control (open bars) and oestradiol treated rabbits (hatched bars). Entire bars represent the total luteal reductase activity when microsomes were prepared in $\mathrm{NaCl}$ buffer and the black area of the bar represents the active portion of luteal reductase activity when microsomes were prepared in $\mathrm{NaF}$ buffer (see text). Values are mean \pm s.e.m. of 4 experiments. Hyst. $=$ hysterectomized.

Table 2. The effect of compactin on rabbit luteal cell progesterone production $(\mathrm{ng} / \mathrm{ml})$ in vitro*

\begin{tabular}{cccccc}
\hline \multirow{2}{*}{$\begin{array}{c}\text { Dose of compactin } \\
(\mu \mathrm{g} / \mathrm{ml})\end{array}$} & $1^{+}$ & 2 & 3 & 4 & 5 \\
\cline { 2 - 6 } & & & & \\
\hline 0 (control) & $27 \cdot 0 \pm 3 \cdot 9$ & $30 \cdot 6 \pm 3 \cdot 1$ & $41 \cdot 5 \pm 5 \cdot 7$ & $45 \cdot 2 \pm 4 \cdot 7$ & $48 \cdot 4 \pm 5 \cdot 9$ \\
$0 \cdot 001$ & $21 \cdot 2 \pm 3 \cdot 4$ & $24 \cdot 2 \pm 6 \cdot 1$ & $36 \cdot 5 \pm 2 \cdot 8$ & $40 \cdot 2 \pm 3 \cdot 7$ & $43 \cdot 9 \pm 4 \cdot 0$ \\
$0 \cdot 01$ & $20 \cdot 9 \pm 3 \cdot 4$ & $29 \cdot 7 \pm 5 \cdot 4$ & $34 \cdot 9 \pm 2 \cdot 8$ & $43 \cdot 2 \pm 5 \cdot 3$ & $41 \cdot 7 \pm 8 \cdot 6$ \\
$0 \cdot 1$ & $26 \cdot 7 \pm 4 \cdot 9$ & $40 \cdot 2 \pm 8 \cdot 5$ & $40 \cdot 7 \pm 6 \cdot 8$ & $50 \cdot 6 \pm 11 \cdot 1$ & $48 \cdot 9 \pm 7 \cdot 9$ \\
$1 \cdot 0$ & $28 \cdot 2 \pm 4 \cdot 9$ & $40 \cdot 5 \pm 4 \cdot 3$ & $41 \cdot 2 \pm 6 \cdot 3$ & $49 \cdot 2 \pm 9 \cdot 4$ & $42 \cdot 9 \pm 5 \cdot 9$ \\
10 & $34 \cdot 1 \pm 6 \cdot 8$ & $42 \cdot 9 \pm 5 \cdot 1$ & $49 \cdot 5 \pm 7 \cdot 2$ & $45 \cdot 8 \pm 9 \cdot 9$ & $47 \cdot 2 \pm 10 \cdot 9$ \\
\hline
\end{tabular}

*Values are mean \pm s.e.m. for 5 incubations in static culture.

†During the first hour cells were exposed to HBSS only; treatment started at Hour 2.

luteal cells during $4 \mathrm{~h}$ of incubation ( $n=5$; Table 2). Progesterone concentrations in media from compactin-treated incubations were not significantly different from control incubations at any compactin concentration tested.

\section{Discussion}

It is well-established that functional luteal cells must have an efficient means of obtaining cholesterol for steriodogenesis (Strauss et al., 1981). The rabbit corpus luteum contains high levels of the rate-limiting enzyme of cholesterol synthesis, $\mathrm{HMG}-\mathrm{CoA}$ reductase, which suggests that de-novo cholesterol synthesis may be the essential pathway through which rabbit luteal cells acquire cholesterol for progesterone production. Since the activity of this enzyme begins to decline after Day 5 of pregnancy (Kovanen et al., 1978) at the time when oestradiol binding to corpora lutea is first 
observed (Mills \& Osteen, 1977), we have examined the possibility that oestradiol regulates the activity of this enzyme during pseudopregnancy. In this study, we found that, when serum oestradiol concentrations were elevated, the total activity of luteal HMG-CoA reductase was not altered during early pseudopregnancy (Day 4) but was decreased in oestradiol-treated intact pseudopregnant rabbits on Days 8 and 12. By Day 16 in intact or Day 20 in hysterectomized pseudopregnant rabbits, oestradiol treatment no longer affected total $\mathrm{HMG}-\mathrm{CoA}$ reductase activity. In contrast, the active form of HMG-CoA reductase, which is considered to represent the enzyme activity in situ (Carr et al., 1980), was unaltered by oestradiol.

De-novo cholesterol synthesis did not seem to play a significant role during short term steroidogenesis in vitro since compactin was without effect on progesterone production by rabbit luteal cells during a 4-h incubation. Although we did not directly confirm that compactin inhibited HMGCoA reductase in our cells, the maximal dose of compactin used $(10 \mu \mathrm{M})$ was $3-7$-fold the amount required to inhibit cholesterol synthesis in human fibroblasts (Kaneko et al., 1978) and human granulosa cells (Tureck \& Strauss, 1982). Similar results (i.e. failure to inhibit steroidogenesis with compactin) have been observed with hamster luteal and granulosa cells during short-term incubations (Silavin \& Strauss, 1983).

HMG-CoA reductase is regulated by two separate mechanisms which involve short-term modulation of the phosphorylated/dephosphorylated enzyme state, and long-term regulation of tissue enzyme concentrations (Beg \& Brewer, 1981). Since prolonged oestrogen treatment did not change the level of active $\mathrm{HMG}-\mathrm{CoA}$ reductase and decreased the total (active + inactive) enzyme activity, oestrogen does not appear to regulate the phosphorylated/dephosphorylated state of the enzyme (short-term regulation) but may regulate the total content of luteal HMG-CoA reductase. These results are consistent with those of Wittmaack et al. (1986) who found that HMG-CoA reductase activity was not significantly altered after oestrogen removal in the rabbit despite a dramatic decrease in serum progesterone. In addition, McNamara \& Rodwell (1972) have demonstrated that steroids can suppress $\mathrm{HMG}-\mathrm{CoA}$ reductase activity solely by decreasing the quantity of reductase protein.

Morphometric analysis has shown that prolonged oestrogen treatment increases the content of luteal lipid droplets, i.e. esterified cholesterol (McLean \& Miller, 1987). Since oestrogen treatment did not alter serum cholesterol concentrations at any time throughout the experiment, increased cholesterol ester stores may have suppressed HMG-CoA reductase activity through feedback inhibition (Brown et al., 1979). This hypothesis is consistent with the findings of Goldstein \& Brown (1974) who showed that cholesterol ester levels were inversely related to reductase activity in cultured fibroblasts. In addition, it has been shown that the direct addition of cholesterol esters to cultured cells suppresses reductase activity more effectively than does cholesterol itself (Watson et al., 1974).

Although oestradiol appears only to exert long-term regulation of rabbit luteal $\mathrm{HMG}-\mathrm{CoA}$ reductase, this enzyme is also acutely affected by changes in serum cholesterol values. When serum cholesterol concentrations were decreased by APP (Morrin et al., 1979) in oestrogen-treated rabbits, the total enzyme activity increased only slightly while the active form of this enzyme was significantly $(P<0.05)$ elevated in APP-treated animals. These results suggest that $\mathrm{HMG}-\mathrm{CoA}$ reductase activity increases to compensate for the loss of exogenous cholesterol. Similar results have been reported for rat luteal tissue after treatment with APP (Christie et al., 1979; Azhar \& Menon, 1981, 1982). Since HMG-CoA reductase activity increases in response to lowered serum cholesterol, it is clear that rabbit luteal tissue can utilize exogenous sources of cholesterol in situ. This suggests that despite high levels of $\mathrm{HMG}-\mathrm{CoA}$ reductase in the rabbit corpus luteum, lipoprotein-derived cholesterol can also be used as a substrate for steroidogenesis. This is consistent with our previous studies which demonstrate that both low-density lipoprotein and high-density lipoprotein can stimulate progesterone production by dissociated rabbit luteal cells in vitro (McLean \& Miller, 1986a). Thus, both de-novo-derived and lipoprotein-derived cholesterol appear to contribute to maintaining stable progesterone output by rabbit luteal cells. 
From these results and those of our previous studies, we suggest that oestradiol indirectly controls HMG-CoA reductase by increasing cholesterol stores, thus decreasing luteal enzyme activity (long-term regulation). Short-term regulation of $\mathrm{HMG-CoA}$ reductase appears to be regulated by serum cholesterol concentrations. These results are consistent with the hypothesis that the luteotrophic role of oestrogen in the rabbit is to maintain a constant steroidogenic pool of cholesterol rather than to regulate directly de-novo cholesterol biosynthesis.

We thank Mary Haizziez and Sharon Jernigan for excellent technical assistance and Eva Ortegon and Elisa Sahagun for careful preparation of the manuscript. Supported by HD-00447, HD 14870, DCB-8415927 and University of Illinois Campus Research Board Grant No. 973.

\section{References}

Allain, C.A., Poon, L.S., Chan, C.S.G., Richmond, W. \& Fu, P.C. (1974) Enzymatic determination of total serum cholesterol. Clin. Chem. 20, 470-475.

Azhar, S. \& Menon, K.M.J. (1981) Receptor mediated gonadotropin action in the ovary. Rat luteal cells preferentially utilize and are acutely dependent upon the plasma-lipoprotein supplied sterols in gonadotropin stimulated steroid production. J. biol. Chem. 256, 5648-5655.

Azhar, S. \& Menon, K.M.J. (1982) Receptor mediated gonadotropin action in gonadal tissue: relationship between blood cholesterol levels and gonadotropin stimulated steroidogenesis in isolated rat Leydig and luteal cells. J. Steroid Biochem. 16, 175-183.

Azhar, S., Khan, I., Chen, Y-D.I., Reaven, G.M. \& Gibori, G. (1985) Regulation of luteal cell 3-hydroxy3-methylglutaryl coenzyme A reductase activity by estradiol. Biol. Reprod. 32, 333-341.

Beg, Z.H. \& Brewer, H.B. (1978) 3-Hydroxy-3-methylglutaryl coenzyme A reductase: regulation of enzymatic activity by phosphorylation and dephosphorylation. Proc. natn. Acad. Sci. U.S.A. 75, 3678-3682.

Beg, Z.H. \& Brewer, H.B. (1981) Regulation of liver 3hydroxy-3-methylglutaryl-CoA reductase. Curr. Top. Cell Regul. 20, 139-184.

Bill, C.H. \& Keyes, P.L. (1983) 17 $\beta$-Estradiol maintains normal function of corpora lutea throughout pseudopregnancy in hypohysectomized rabbits. Biol. Reprod. 28, 608-617.

Bradford, M.N. (1976) A rapid and sensitive method for the quantitation of microgram quantities of protein utilizing the principle of protein-dye binding. Analyt. Biochem. 72, 248-254.

Brown, M.S. \& Goldstein, J.L. (1974) Familial hypercholesterolemia: defective binding of lipoproteins to cultured fibroblasts associated with impaired regulation of 3-hydroxy-3-methylglutaryl coenzyme A reductase activity. Proc. natn. Acad. Sci. U.S.A. 71, $788-792$.

Brown, M.S. \& Goldstein, J.L. (1979) Receptor-mediated endocytosis: insights from the lipoprotein receptor system. Proc. natn. Acad. Sci. U.S.A. 76, 3330-3337.

Brown, M.S., Kovanen, P.T. \& Goldstein, J.L. (1979) Receptor-mediated uptake of lipoprotein cholesterol and its utilization for steroid synthesis in the adrenal cortex. Recent Prog. Horm. Res. 35, 215-249.

Carr, B.R., Mikhail, G. \& Flickinger, G.L. (1971)
Columm chromatography of steroids on sephadex LH-20. J. clin. endocr. Metab. 33, 358-360.

Carr, B.R., McDonald, P.C. \& Simpson, E.R. (1980) The regulation of de novo synthesis of cholesterol in the human fetal adrenal gland by low density lipoprotein and adrenocorticotropin. Endocrinology 107, 1000-1006.

Christie, M.H., Strauss, J.F., III \& Flickinger, G.J. (1979) Effect of reduced blood cholesterol on sterol and steroid metabolism by rat luteal tissue. Endocrinology 105, 92-98.

Day, S.L. \& Birnbaumer, L.B. (1980) Corpus luteum function and adenylyl cyclase stimulability in the rat after an estradiol benzoate induced ovulatory surge of luteinizing hormone: role of prolactin. Endocrinology 106, 382-389.

Dugan, R.E., Ness, G.C., Lakshmanan, M.R., Nepokroeff, C.M. \& Porter, J.W. (1974) Regulation of hepatic 3-hydroxy-3-methylglutaryl coenzyme A reductase by the interplay of hormones. Archs Biochem. Biophys. 161, 499-504.

Edwards, P.A. (1973) Effect of adrenalectomy and hypophysectomy on the circadian rhythm of 3-hydroxy-3methylglutaryl coenzyme $A$ reductase activity in rat liver. J biol. Chem. 248, 2912-2917.

England, B.G., Niswender, G.D. \& Midgley, A.R. (1974) Radioimmunoassay of estradiol-17 $\beta$ without chromatography. J. clin. Endocr. Metab. 28, 42-50.

Gibori, G., Antczak, E. \& Rothchild, I. (1977) The role of estrogen in the regulation of luteal progesterone secretion in the rat during the period after day 12 of pregnancy. Endocrinology 100, 1483-1495.

Goldfarb, S. (1972) Submicrosomal localization of hepatic 3-hydroxy-3-methylglutaryl coenzyme A reductase. FEBS Letters 24, 153-155.

Goldstein, J.L. \& Brown, M.S. (1974) Binding and degradation of low density lipoproteins by cultured human fibroblasts. J. biol. Chem. 249, 5153-5162.

Guder, W., Nolte, I. \& Wieland, O. (1968) The influence of thyroid hormones on 3-hydroxy-3-methylglutaryl coenzyme A reductase of rat liver. Eur. J. Biochem. 4, 273-278.

Holt, J.A., Keyes, P.L., Brown, J.M. \& Miller, J.B. (1975) Premature regression of corpora lutea in pseudopregnant rabbits following the removal of polydimethylsiloxane capsules containing $17 \beta$ estradiol. Endocrinology 97, 76-82. 
Huber, J., Latzin, S., Langguth, O., Brauser, B., Gabel, V.P. \& Hamprecht, B. (1973) The influence of bilateral superior cervical ganglionectomy, continuous light and continuous darkness on the diurnal rhythm of hydroxymethylglutaryl-coenzyme A reductase in rat liver. FEBS Letters 31, 261-265.

Ingebritsen, T.S., Parker, R.A. \& Gibson, D.M. (1981) Regulation of liver hydroxymethylglutaryl-CoA reductase by a bicyclic phosphorylation system. $J$. biol. Chem. 256, 1138-1144.

Kandutsch, A.A. \& Packie, R.M. (1970). Comparison of the effects of some $\mathrm{C}_{27^{-}}, \mathrm{C}_{21^{-}}$, and $\mathrm{C}_{19^{-}}$-steroids upon hepatic sterol synthesis and hydroxymethylglutarylCoA reductase activity. Archs Biochem. Biophys. 140, $122-1230$.

Kaneko, I., Hazama-Shimada, Y. \& Endo, A. (1978) Inhibitory effects on lipid metabolism in cultured cells of ML-236B, a potent inhibitor of 3-hydroxy3-methylglutaryl-coenzyme A reductase. Eur. $J$. Biochem. 87, 813-821.

Kovanen, P.T., Goldstein, J.L. \& Brown, M.S. (1978) High levels of 3-hydroxy-3-methylglutaryl coenzyme A reductase activity and cholesterol synthesis in the ovary of the pregnant rabbit. J. biol. Chem. 253, 5126-5132.

McLean, M.P. \& Miller, J.B. (1985) Steroidogenic effect of $17 \beta$-estradiol on rabbit luteal cells in vitro: estrogen induced maintenance of progesterone production, Biol. Reprod. 33, 459-469.

McLean, M.P. \& Miller, J.B. (1986a) Lipoprotein stimulated and estradiol maintained progesterone secretion by dissociated rabbit luteal cells in vitro. Biol. Reprod. 34, 642-654.

McLean, M.P. \& Miller, J.B. (1986b) Indirect regulation of 3-hydroxy-3-methylglutaryl coenzyme A reductase by estradiol in the rabbit corpus luteum. Biol. Reprod. 34 (Suppl.), 127, Abstr. 155.

McLean, M.P. \& Miller, J.B. (1987) Quantitative analysis of oestrogen induced morphological changes in the rabbit corpus luteum. Cytobios 49, 73-84.

McNamara, D.J. \& Rodwell, V.W. (1972) Biochemical Regulatory Mechanisms in Eukaryotic Cells. Wiley, New York.

Miller, J.B. \& Keyes, P.L. (1976) A mechanism for regression of the rabbit corpus luteum: uterineinduced loss of luteal responsiveness to $17 \beta$-estradiol. Biol. Reprod. 15, 511-518.

Miller, J.B. \& Keyes, P.L. (1978) Transition of the rabbit corpus luteum to estrogen dependence during early luteal development. Endocrinology 102, 31-38.

Miller, J.B. \& Toft, D.O. (1983) Characterization and physiological variation of estrogen receptors in rabbit corpora lutea throughout pregnancy and pseudopregnancy: the effect of hysterectomy and sustained estradiol treatment. Biol. Reprod. 29, 620-629.

Mills, T.M. \& Osteen, K.G. (1977) 17 $\beta$-estradiol receptor and progesterone and $20 \alpha$-hydroxy-4-pregnen-3-one content of the developing corpus luteum of the rabbit. Endocrinology 101, 1744-1750
Morrin, R.J., Burkart, W. \& Spikantaiah, M.V. (1979) Effects of 4-aminopyrazolopyrimidine on rabbit plasma cholesterol, platelet 3-hydroxy-3-methylglutaryl coenzyme A reductase and platelet aggregation. Biochem. Pharmacol. 28, 1217-1219.

Mukherjee, S. \& Bhose, A. (1968) Studies on estrogen regulation of cholesterol biosynthesis in rat liver microsomes. Biochem. Biophys. Acta 164, 357-368.

Rodbard, D., Huston, J. \& Munson, P. (1980) BASRIARIA data processing from basic programs. Biomedical computing technology information center. Vanderbilt Medical Center, Nashville, TN.

Schoenheimer, R. \& Breusch, F. (1933) Synthesis and destruction of cholesterol in the organism. J. biol. Chem. 103, 439-448.

Shapiro, D.L. \& Rodwell, V.W. (1972) Fine structure of the cyclic rhythm of 3-hydroxy-3-methylglutaryl coenzyme A reductase. Biochemistry, N.Y. 11, 1042-1045.

Silavin, S.L. \& Strauss, J.F. (1983) Progesterone production by hamster granulosa and luteal cells during short-term incubation. Effects of lipoproteins, compactin and 25-hydroxycholesterol. Biol. Reprod. 29, $1163-1171$.

Strauss, J.F., Tanaka, T., MacGregor, L. \& Tureck, R.W. (1981) Regulation of cholesterol acquisition and utilization in the corpus luteum. Adv. exp. Med. Biol. 147, 303-320.

Tureck, R.W. \& Strauss, J.F. (1982) Progesterone synthesis by luteinized human granulosa cells in culture: the role of de novo sterol synthesis and lipoproteincarried sterol. J. clin. Endocr. Metab. 54, 367-373.

Watson, J.A., Kirsten, E.S. \& Quent, J.B. (1974) Steroid specificity for the regulation of 3-hydroxy-3-methylglutaryl coenzyme A reductase activity in cultured hepatoma cells. Fedn Proc. Fedn Am. Socs exp. Biol. 33, Abstr. No. 1573.

White, L.W. (1972) Stimulation of 3-hydroxy-3-methylglutaryl coenzyme A reductase by insulin. Circulation, Suppl. 2, Abstr. No. 253.

Wilce, P.A., Leijten, L. \& Martin, L. (1984) Stimulation of 3-hydroxy-3-methylglutaryl coenzyme A reductase in mouse uterine epithelial cells by estradiol. Biochem. J. 218, 849-855.

Wittmaack, F.M., Holy, J.A. \& Schreiber, J.R. (1986) Cholesterol metabolism in estrogen-sensitive progestin synthesis by rabbit corpus luteum. Am. J. Physiol. 251, E457-463.

Zar, J.H. (1974) Biostatistical Analysis. Prentice Hall Inc., Englewood Cliffs.

Zilversmit, D.B., Hughes, L.B. \& Remington, M. (1972) Hypolipidemic effect of pregnancy in the rabbit. $J$. Lipid. Res. 13, 750-756. 